\title{
PERANCANGAN WEBSITE SEBAGAI MEDIA PROMOSI DAN PENJUALAN PADA HOME INDUSTRY ABON
}

\author{
SHANTY KUSUMA DEWI DAN ANNISA KESY GARSIDE \\ Jurusan Teknik Industri, Fakultas Teknik, Universitas Muhammadiyah Malang \\ Jl. Raya Tlogomas 246, Malang 65144, Jawa Timur
}

Surel : shanty.kusumadewi@gmail.com,annisa_garside@yahoo.com

\begin{abstract}
ABSTRAK
Kegiatan pemasaran yang dilakukan oleh home industry abon Lestari Jaya Pangan saat ini masih kurang dikelola dengan baik. Penjualan masih dilakukan secara konvensional dengan menawarkan kepada toko-toko dan swalayan serta melalui perantara sehingga penjualan produk abonnya masih terbatas di sekitar wilayah Malang. Metode promosi yang dilakukan juga sebatas brosur dan ikut serta ketika ada event pameran lokal maupun nasional yang diselenggarakan oleh pemerintah. Untuk mengatasi permasalahan tersebut maka dilakukan perancangan website untuk mendukung kegiatan pemasaran dan penjualan abon home industri tersebut. Perancangan website menggunakan sistem penjualan online dengan tool Content Management System (CMS) Opencart. Dengan adanya website ini, kegiatan pemasaran akan lebih efektif dan bisa menaikkan omset penjualan.
\end{abstract}

Kata Kunci: website, pemasaran, penjualan, content management system

\begin{abstract}
Marketing activity which is performed by a home industry of abon namely Lestari Jaya Pangan currently is not completely well established. Selling activity is conventionally run through offering the product to stores, market and also through retailer. Its affects the sale to be limited only nearby region of Malang. Promotion strategy also limited by using brochure and participating either local or national fair which is organized by goverment. In order to tackle the issue, the website is needed to be designed to support marketing and selling activity of its product particularly abon. website is designed by using oneline selling system with content management system (CMS) opencart. Through the website, marketing activity is more effective and able to increase income.
\end{abstract}

Key words: website, marketing, selling, content management system

\section{PENDAHULUAN}

Pesatnya persaingan bisnis saat ini menuntut pelaku bisnis untuk selalu mengikuti perkembangan pasar maupun keinginan dari pasar. Kotler (1998) mengemukakan bahwa pasar terdiri dari semua pelanggan potensial yang memiliki kebutuhan dan keinginan tertentu serta mau dan mampu turut dalam pertukaran untuk memenuhi kebutuhan atau keinginan itu. Suatu perusahaan dalam menjalankan aktivitasnya harus efektif menjalankan konsep pemasaran agar keuntungan yang diharapkan dapat terealisasi dengan baik. Ini menandakan bahwa kegiatan pemasaran dalam perusahaan harus dikoordinasi dan dikelola dengan cara yang lebih baik.

Kegiatan pemasaran yang dilakukan oleh home industry abon Lestari Jaya Pangan saat ini masih kurang dikelola dengan baik. Menurut Kotler dan Amstrong (2003) pemasaran merupakan suatu proses sosial dan manajerial yang membuat individu dan kelompok memperoleh apa yang mereka butuhkan dan inginkan lewat penciptaan dan pertukaran timbal balik produk dan nilai dengan orang lain. Home industry abon "Lestari Pangan Jaya" yang berlokasi di 
Desa Mojorejo-Kota Batu mengalami kendala keterbatasan waktu dalam mempromosikan. Penjualan masih dilakukan secara konvensional dengan menawarkan kepada toko-toko dan swalayan serta melalui perantara sehingga penjualan produk abonnya masih terbatas di sekitar wilayah Malang. Metode promosi yang dilakukan juga sebatas brosur dan ikut serta ketika ada event pameran lokal maupun nasional yang diselenggarakan oleh pemerintah.

Bidang bisnis dan perdagangan yang berkembang saat ini sangat terpengaruh dengan perkembangan teknologi informasi khususnya dalam penggunaan internet (Jauhari, 2010). Dengan adanya internet dan Information and Communication Technology (ICT), proses pemasaran dan penjualan dapat dilakukan kapan saja tanpa terikat ruang dan waktu (Quaddus and $\mathrm{Xu}, 2008$; Jinling et al., 2009). Dengan kemampuan internet yang bisa mengirimkan berbagai bentuk data seperti teks, grafik, gambar, suara, animasi, atau bahkan video, maka banyak kalangan bisnis yang memanfaatkan teknologi ini dengan membuat homepage untuk mempromosikan usahanya. Pemasaran dengan metode konvensional memerlukan biaya tinggi, misalnya membuka cabang baru, ikut pameran, pembuatan dan penyebaran brosur, dan sebagainya. Berkembangnya internet menjadi sarana yang efisien untuk membuka jalur pemasaran model baru bagi produk UKM. Disamping biayanya relatif murah, dengan memanfaatkan internet penyebaran informasi akan lebih cepat dan jangkauannya lebih luas (Rizal dkk.,2013; Supardi, 2009). Pemasaran produk UKM melalui e-commerce dapat melayani banyak pembeli dalam waktu bersamaan dan pembeli juga tidak perlu antri untuk menunggu dilayani (Nugrahani, 2011). Oleh karena itu, tujuan dari penelitian ini adalah merancang website sebagai media promosi dan penjualan. Dengan adanya home page diharapkan dapat mempermudah home industry untuk menyebarkan informasi tentang produk abon yang diproduksi dan mempermudah transaksi penjualan dengan cara online.

\section{METODE}

Teknik pengumpulan data yang dilakukan dengan beberapa tahapan antara lain dengan observasi, interview, dan brainstorming. Data yang dibutuhkan meliputi data umum home industry, data pendukung perancangan program serta user requirement yang berisi keinginan serta atribut yang diperlukan pada saat menggunakan software, dan fungsi-fungsi lain yang diperlukan oleh pengguna.

\section{Konsep Dasar Internet dan Aplikasi Website}

Internet merupakan kependekan dari interconnection-networking. Internet adalah jaringan komputer global yang menghubungkan sebuah komputer dengan komputer lain yang ada di seluruh dunia dengan menggunakan standart Internet Protocol Suite (TCP/IP). TCP/ IP memiliki teknik mengidentifikasi dengan menggunakan penomoran yang dinamakan Internet Protocol Address (IP Address). Nomor yang ada tersebut dapat terhubung dengan komputer lain dalam sebuah jaringan atau dalam jaringan lokal (Nugroho, 2004). Dengan adanya internet komputer-komputer yang saling terhubung tersebut dapat saling bertukar data dan informasi tanpa terkendala oleh jarak.

WWW merupakan singkatan World Wide Web sering disebut dengan web. Menurut Syafrizal (2005), web adalah sebuah sistem dimana informasi dalam bentuk teks, gambar, suara, dan lain-lain dipresentasikan dalam bentuk hypertext dan dapat diakses oleh perangkat lunak yang disebut browser. Dengan demikian seseorang dapat menciptakan puluhan bahkan ratusan aplikasi yang berjalan di bawah web (under web). Teknik pembuatan website dapat dilakukan dengan beberapa macam pemrograman maupun non pemrograman.

Salah satu penerapan ICT dan internet dalam bidang bisnis dan perdagangan adalah electronic commerce (e-commerce). E-commerce dapat didefinisikan sebagai aplikasi dan penerapan dari e-bisnis yang berkaitan dengan transaksi komersial, seperti: transfer dana secara 
elektronik, SCM (supply chain management), epemasaran (e-marketing), atau pemasaran online (online marketing), pemrosesan transaksi online (online transaction processing), pertukaran data elektronik (electronic data interchange/EDI), promosi produk, dan lain-lain.

Manfaat dan keuntungan menggunakan $e$ commerce adalah media promosi dalam rangka untuk meningkatkan volume penjualan, baik untuk penjualan online maupun konvensional (Supardi, 2009). Di samping keuntungan tersebut, ternyata hasil beberapa penelitian menunjukkan bahwa efektivitas penggunaan $e$-commerce dalam mendongkrak peningkatan volume penjualan dan mempromosikan produk-produk industri cukup tinggi (Alexander, 2002; Supardi, 2009).

Tahapan-tahapan yang akan dilaksanakan dalam perancangan website meliputi :

1. Analisis Sistem

Pada tahap ini dilakukan identifikasi dan mengevaluasi permasalahan serta menganalisis apa saja yang menjadi penyebabnya. Analisis yang dilakukan dengan menggunakan analisis PIECES. Analisis PIECES (Performance, Information, Economic, Control, Effiency, Services) bertujuan untuk mengetahui sistem yang sedang berjalan layak atau tidak.

2. Analisis Kebutuhan Sistem

Analisis kebutuhan informasi dibedakan menjadi 2 jenis yaitu kebutuhan fungsional dan kebutuhan non fungsional. Kebutuhan fungsional adalah jenis kebutuhan yang berisi proses-proses apa saja yang nantinya dilakukan oleh sistem. Kebutuhan fungsional juga berisi informasi-informasi apa saja yang harus ada dan dihasilkan sistem. Kebutuhan non fungsional adalah tipe kebutuhan yang berisi properti perilaku yang dimiliki oleh sistem.

3. Desain

Tahap desain merupakan spesifikasi sistem yang dirancang secara lengkap yang dibuat berdasarkan kebutuhan yang telah direkomendasikan pada tahapan sebelumnya.
Pada tahapan ini langkah-langkahnya sebagai berikut :

a. Membuat diagram use case. Diagram use case merupakan gambaran secara grafis dari proses bisnis berdasarkan perspektif pengguna sistem. Use case terdiri atas diagram untuk use case dan aktor. Aktor mempresentasikan orang yang akan mengoperasikan atau orang yang berinteraksi dengan aplikasi sistem. Use case merepresentasikan operasi-operasi yang dilakukan oleh aktor. Use case digambarkan dalam bentuk elips dengan nama operasi dituliskan didalamnya. Aktor yang melakukan operasi dihubungkan dengan garis lurus ke use case.

b. Membuat diagram konteks (context diagram). Context Diagram merupakan sebuah diagram aliran data yang memfokuskan pada aliran data dari dan ke dalam sistem, serta memproses datadata tersebut. Komponen-komponen dasar dari setiap program komputer yang digambarkan secara mendetail, dapat digunakan untuk menganalisis keakuratan dan kompetensi sistem (Kendall dan Kendall, 2003).

c. Membuat Entity Relationship Diagram (ERD). Fathansyah (2001) menyatakan bahwa ERD merupakan diagram yang berisi komponen- komponen himpunan entitas dan himpunan relasi yang masingmasing dilengkapi dengan atribut-atribut yang merepresentasikan seluruh fakta yang ditinjau.

d. Membuat Data Flow Diagram (DFD). Data Flow Diagram merupakan teknik analisis data terstruktur yang merepresentasikan proses-proses data di dalam organisasi (Kendall dan Kendall, 2003).

e. Membuat subsistem database. Database adalah suatu koleksi data komputer yang terintegrasi, diorganisasikan, dan disimpan dengan suatu cara yang memudahkan pengambilan kembali (McLeod, 2004).

f. Membuat subsistem user interface dimana dalam bentuk tampilan grafis yang berhubungan langsung dengan pengguna, dimana fungsinya untuk menghubungkan antara pengguna dengan sistem operasi. 
4. Implementasi

Tahap ini merupakan tahapan penerapan semua hasil desain pada tahap sebelumnya dibuat dalam bentuk website. Pada perancangan website untuk home industry abon Lestari Jaya Pangan menggunakan Content Management System (CMS). Menurut Gunadi dan Lirva (2007), CMS bisa didefinisikan sebagai pengelolaan isi atau konten. CMS adalah aplikasi web yang memiliki sistem sedemikian sehingga memberi kemudahan kepada para pengguna sekaligus juga pengelolanya (Iqbal, 2009). CMS bisa didefinisikan sebagai software yang mampu mengelola isi atau content dari sebuah website seperti melakukan publikasi, edit ataupun menghapus sebuah content. Namun, pengelolaan ini hanya bisa dilakukan oleh orang-orang yang telah diberikan hak untuk melakukannya. Termasuk ke dalam kategori konten ini, bisa saja berupa tulisan, gambar, file, ataupun yang lainnya.

CMS pertama kali muncul sebagai jawaban atau solusi dari kebutuhan manusia akan penyediaan informasi yang sangat cepat. website yang dulu sering kita lihat terkadang sangat sederhana, hanya mengandalkan bahasa pemrograman HTML dan beberapa gambar serta informasi yang statis. Pemilik website berusaha sebaik mungkin menampilkan informasi secukupnya kepada para pengunjung. Setiap kali ada perubahan informasi atau ingin menambah konten atau artikel, pemilik web yang belum tahu banyak tentang pemrograman web terpaksa haruslah berhubungan dengan webmaster untuk menangani hal ini. Pihak inilah yang nantinya akan mengadakan perubahan terhadap isi website. Jika hal yang sama terjadi secara terus menerus maka cukup banyak diperlukan tenaga, waktu dan biaya untuk memproses semuanya. Penggunaan CMS saat ini telah berkembang pesat hingga pemakaiannya juga telah merambah pada dunia bisnis (Rahmadi, 2010).

\section{HASIL DAN PEMBAHASAN}

\section{Analisis Sistem}

Sistem penjualan dan promosi yang diterapkan di home industry abon Lestari Jaya Pangan masih mempunyai beberapa kelemahan. Analisis sistem lama dapat ditinjau dengan analisis PIECES sebagai berikut :

Tabel 1. Analisis PIECES

\begin{tabular}{|c|c|}
\hline Jenis Analisis & Kelemahan Sistem Lama \\
\hline Performance & $\begin{array}{l}\text { Kinerja dari sitem penjualan offline yang ada membutuhkan waktu dan } \\
\text { perhatian khusus. Sistem pemasaran home industry Lestari Jaya Pangan juga } \\
\text { kurang efektif. }\end{array}$ \\
\hline Information & Sistem informasi penjualan yang ada masih berupa brosur produk. \\
\hline Economy & $\begin{array}{l}\text { Biaya promosi dengan sistem lama membutuhkan dana yang cukup besar } \\
\text { sekitar Rp } 600.000 \text {,- dan biaya yang dikeluarkan untuk promosi belum } \\
\text { sebanding dengan peningkatan pendapatan yang diperoleh. }\end{array}$ \\
\hline Control & $\begin{array}{l}\text { Sistem penjualan offline yang saat ini berjalan masih konvensional dimana } \\
\text { proses pendataan penjualan kurang terorginisir dengan baik. Sistem kontrol } \\
\text { terhadap informasi promosi juga cukup sulit dilakukan apabila terjadi } \\
\text { kesalahan dalam pencetakan brosur. }\end{array}$ \\
\hline Efficiency & $\begin{array}{l}\text { Efisiensi sistem masih sangat kurang, misalkan untuk mengetahui jumlah } \\
\text { produk yang dipesan dan berapa jumlah stok produk yang masih ada } \\
\text { membutuhkan waktu yang cukup lama karena belum tercatat dengan baik. } \\
\text { Sehingga pengambilan keputusan untuk pengiriman atau perencanaan } \\
\text { produksi sering terjadi permasalahan. }\end{array}$ \\
\hline Service & $\begin{array}{l}\text { Pelayanan yang diberikan kepada konsumen sangat terbatas. Proses } \\
\text { pelayanan hanya terbatas pada toko yang menjual produk atau pada saat event } \\
\text { pameran diadakan. }\end{array}$ \\
\hline
\end{tabular}




\section{Analisis Kebutuhan Sistem}

Analisis kebutuhan sistem dilakukan untuk memahami apa saja yang dibutuhkan oleh pengguna. Untuk mempermudah analisis sistem dalam menentukan kebutuhan secara lengkap maka analisis sistem dibagi menjadi dua yaitu analisis kebutuhan fungsional dan analisis kebutuhan non fungsional.

\section{Analisis Kebutuhan Non Fungsional}

Kebutuhan ini adalah tipe kebutuhan yang berisi properti perilaku yang dimiliki oleh sistem. Beberapa poin tersebut apabila diaplikasikan pada kebutuhan non fungsional untuk sistem website antara lain :

- Analisis kebutuhan perangkat keras. Perangkat keras yang dibutuhkan untuk perancangan sistem antara lain : satu unit laptop dengan processor Intel Core i5, harddisk $500 \mathrm{~GB}$, printer, dan modem untuk konektivitas internet.

- Analisis kebutuhan perangkat lunak. Kebutuhan perangkat lunak yang digunakan antara lain : sistem operasi microsoft windows, Xampp 2.5 installer, Mozilla firefox atau google chrome sebagai web browser, Opencart (CMS) i5.3.1 stable full package.

- Analisis kebutuhan sumber daya manusia pengembang dan pengguna website antara lain: webmaster (admin) merupakan seorang yang dapat mengolah dan mendesain interface website serta mengembangkan website tersebut. User (pengguna) yaitu semua orang yang dapat masuk untuk melihat website dan memiliki hak untuk mengakses website baik dengan cara mendaftar menjadi anggota atau tidak. Pengguna tidak mempunyai hak untuk mengelola ataupun mengendalikan website secara keseluruhan.

\section{Analisis Kebutuhan Fungsional}

Kebutuhan fungsional berisi proses-proses yang nantinya akan dilakukan oleh sistem. Kebutuhan fungsional juga berisi informasi yang harus ada dan dihasilkan oleh sistem. Kebutuhan fungsional pada umumnya menunjukkan fasilitas yang dibutuhkan dan aktivitas apa yang terjadi dalam sistem baru. Kebutuhan fungsional website home industry abon dapat ditunjukkan dengan diagram IPO pada Gambar 1.

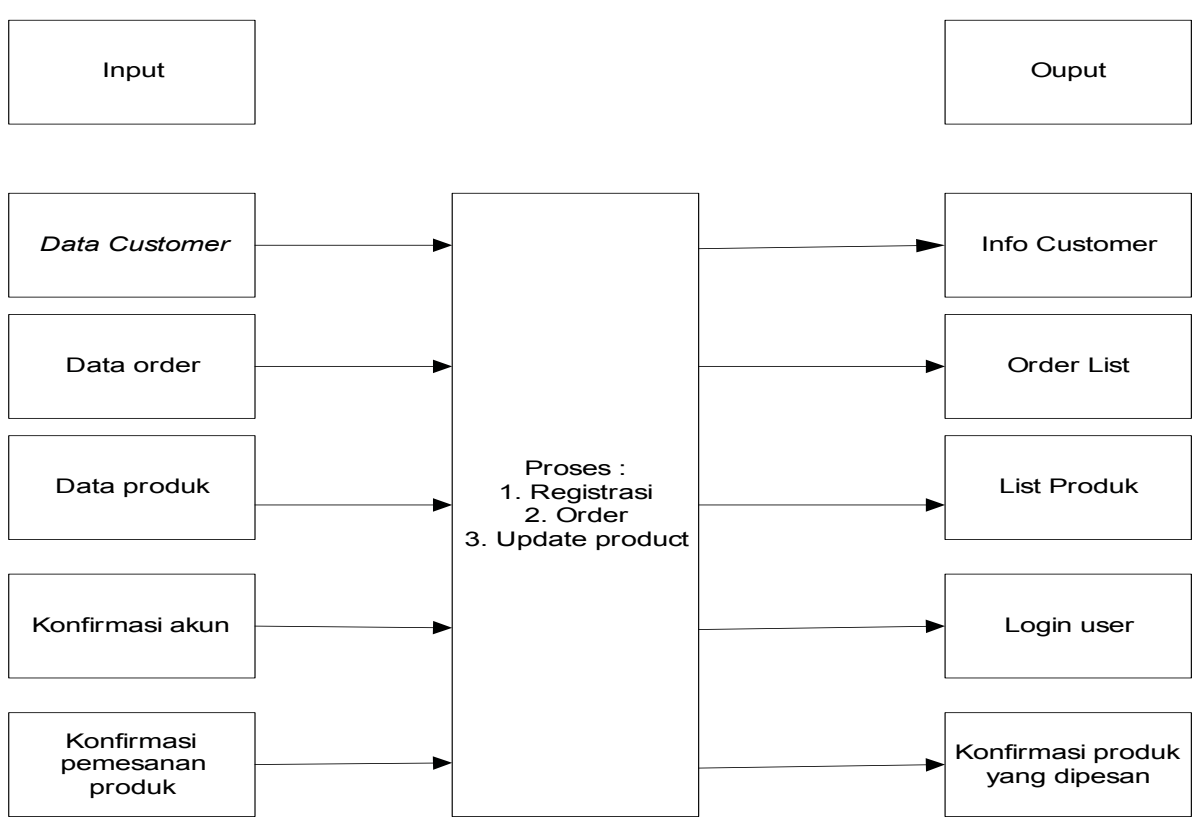

Gambar 1. Diagram IPO (Input, Process,Ouput) 
Berdasarkan diagram IPO dapat diketahui bahwa setiap user mempunyai berbagai kebutuhan yang dibagi dalam lima bagian yaitu : input, proses, dan output. Dari user requirement yang telah ditentukan digunakan untuk menentukan spesifikasi sistem yang akan dibuat. Berikut ini adalah spesifikasi sistem yang dibuat, antara lain sebagai berikut :

1. Sistem terdiri dari dua halaman login, yaitu halaman admin dan halaman untuk customer.

2. Halaman admin merupakan halaman yang hanya dapat diakses oleh admin, dalam hal ini adalah pemilik home industri abon. Pada halaman admin, admin dapat melakukan proses penambahan produk, update informasi, pengelolaan dan kontrol terhadap keseluruhan data.

3. Halaman customer merupakan halaman publik yang dapat diakses oleh pengunjung website yang ingin melihat dan membeli produk abon. Pada halaman customer terdapat fitur-fitur untuk melihat produk, melakukan pemesanan produk. Pada halaman ini sebelum melakukan pemesanan produk, customer bisa melakukan registrasi atau tidak untuk bisa melakukan proses pembelian.

\section{Perancangan dan Pengembangan Sistem}

\section{Desain Konseptual}

Tahapan desain adalah tahapan dimana spesifikasi sistem secara lengkap dibuat berdasarkan kebutuhan yang telah direkomendasikan pada tahap sebelumnya. Dalam tahap desain konseptual terdapat dua komponen utama yaitu desain database logis dan desain hierarki menu. Perancangan database merupakan langkah awal dalam pembuatan aplikasi untuk menunjang program pemasaran dan penjualan pada home industry abon. Desain database pada tahap desain konseptual dapat dilakukan dengan data modelling dimana digambarkan dengan ERD (Entity Relationship Diagram) sedangkan

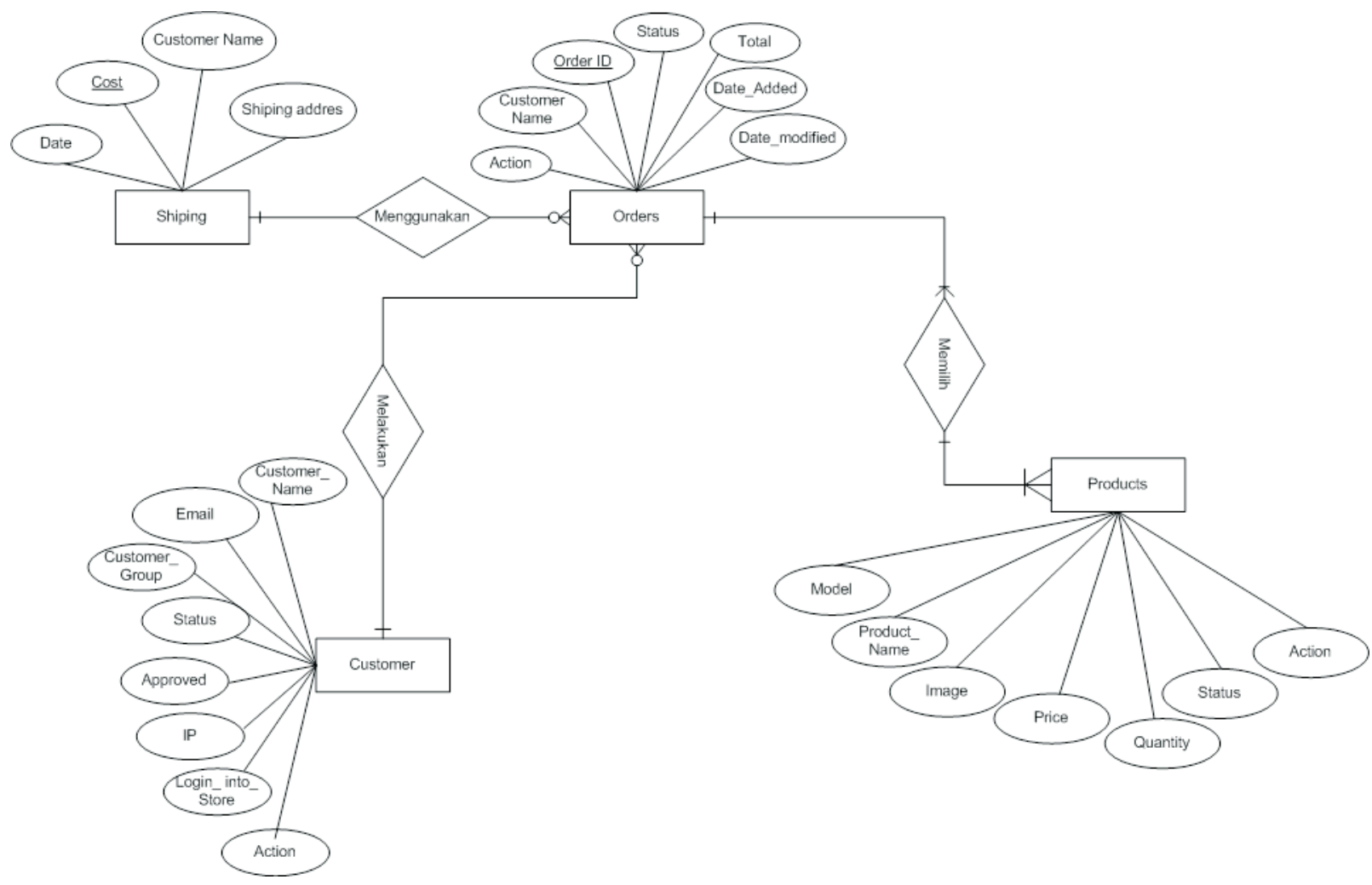

Gambar 2. Entity Relationship Diagram 
process modelling digambarkan dengan diagram use case, diagram konteks, dan DFD (Data Flow Diagram).

\section{Data Modelling}

Data modelling digunakan untuk menggambarkan data dan dikembangkan dalam suatu sistem bisnis. Dalam data modelling ini diperlukan ERD untuk mengidentifikasi dan menetapkan seluruh entitas yang terlibat serta atribut masing-masing entitas. Berikut ERD dari home industry abon yang ditunjukkan pada Gambar 2.

\section{Process Modelling}

Process modelling menggambarkan bagaimana proses bisnis beroperasi, mengilustrasikan aktivitas-aktivitas yang dilakukan dan bagaimana data berpindah diantara aktivitas-aktivitas tersebut.

\section{Diagram Use Case (Use Case Diagram)}

Diagram use case pada website e-commerce home industry abon ini ditunjukkan pada Gambar 3. Pada diagram tersebut yang menjadi aktor adalah customer dan administrator. Pada aktor admin, admin melakukan login dan use

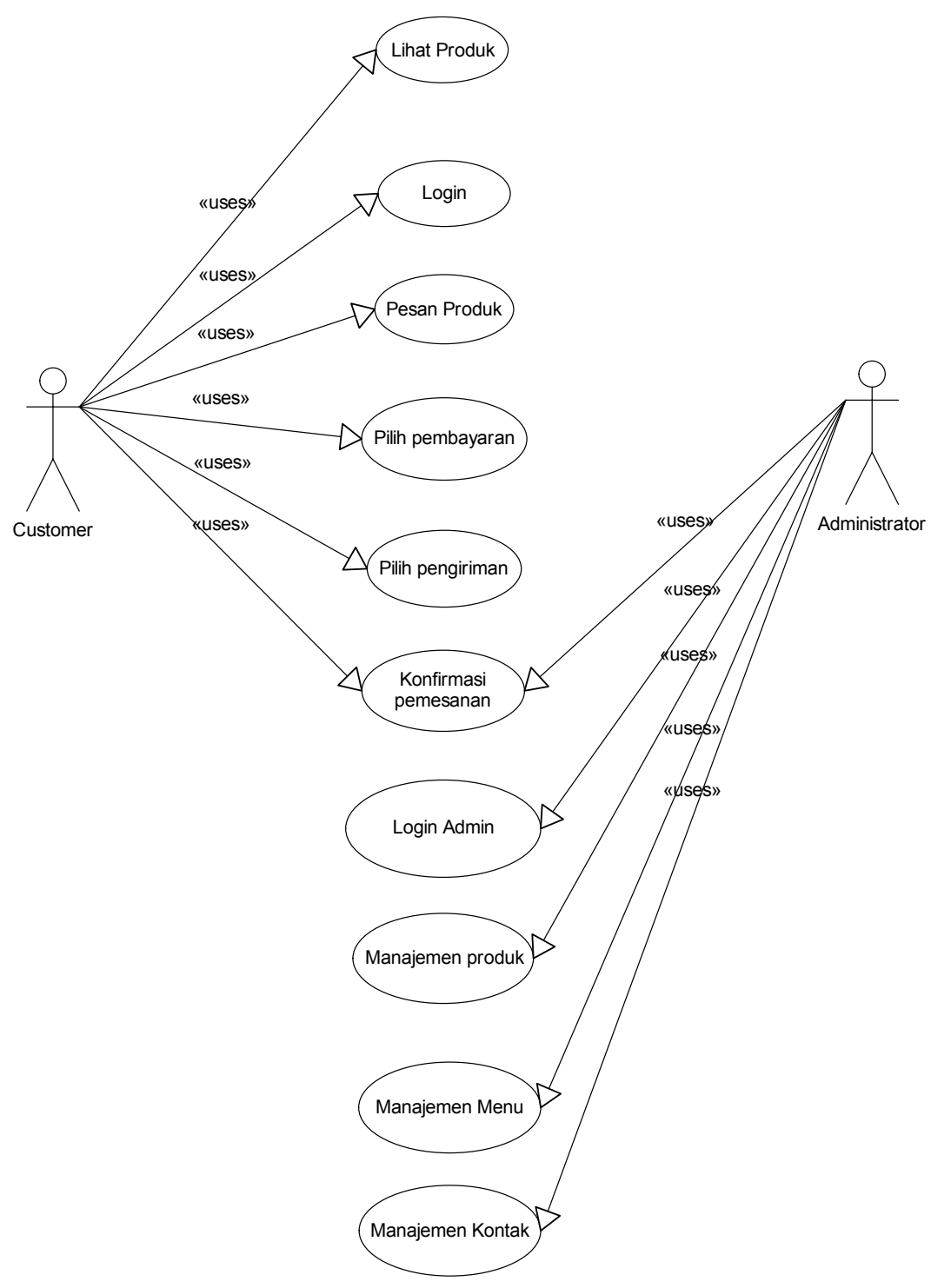

Gambar 3. Use Case Diagram 


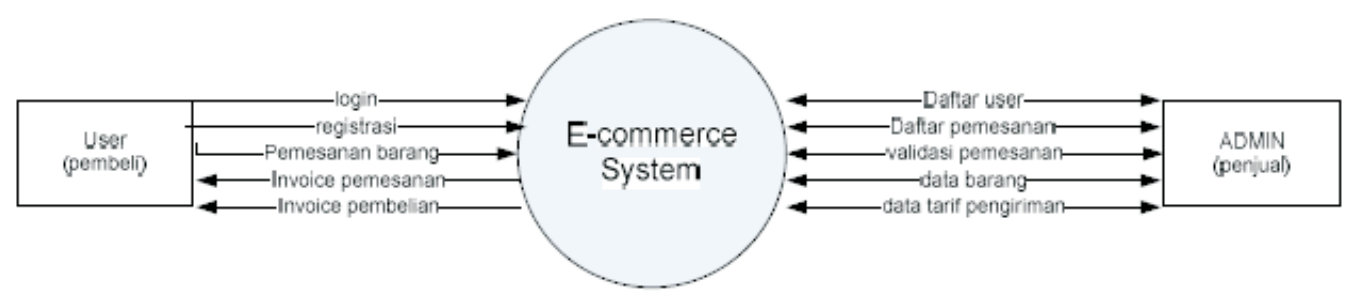

Gambar 4. Diagram Konteks pada Website e-Commerce

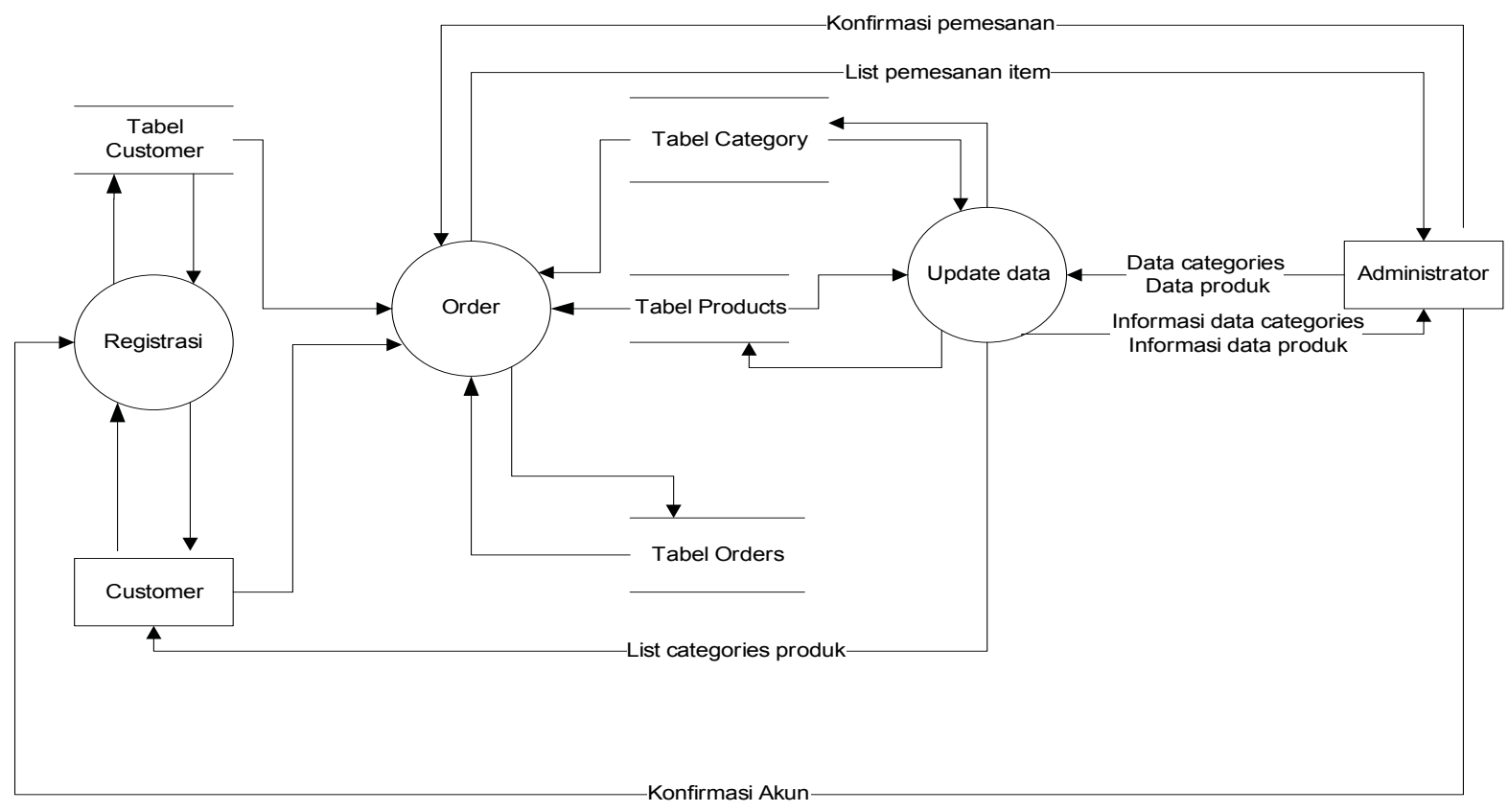

Gambar 5. DFD Level 0

case pada admin antara lain konfirmasi order dari customer, manajemen produk, manajemen kontak, dan manajemen menu. Sedangkan pada aktor customer, use case yang ada antara lain login customer, lihat produk, pilih produk, pilih pengiriman, pilih pembayaran, dan konfirmasi order.

\section{Diagram Konteks}

Diagram konteks pada Website e-commerce home industry abon ini ditunjukkan pada Gambar 4.

\section{Data Flow Diagram Level 0}

Data Flow Diagram Level 0 merupakan pengembangan dari diagram konteks. DFD level 0 menggambarkan proses satu persatu. Pada Gambar 5 dapat dilihat bahwa proses bisnis yang ada pada web home industry abon ada tiga yaitu pemesanan (order), registrasi, dan update informasi oleh admin. Pada proses pemesanan customer memilih produk yang akan dibeli dan pada proses login customer bisa melakukan registrasi untuk mendapatkan akun. Pada proses update admin bisa melakukan input informasi.

\section{Data Flow Diagram Level 1}

Data Flow Diagram Level 1 menggambarkan proses penyusun utama pada DFD level 0 juga menunjukkan bagaimana aliran informasi dari setiap proses. Pada DFD level 1 pada Gambar 6 dapat dilihat bahwa customer tidak harus melakukan login terlebih dahulu untuk melakukan proses pembelian produk, sehingga customer bisa langsung melakukan proses 


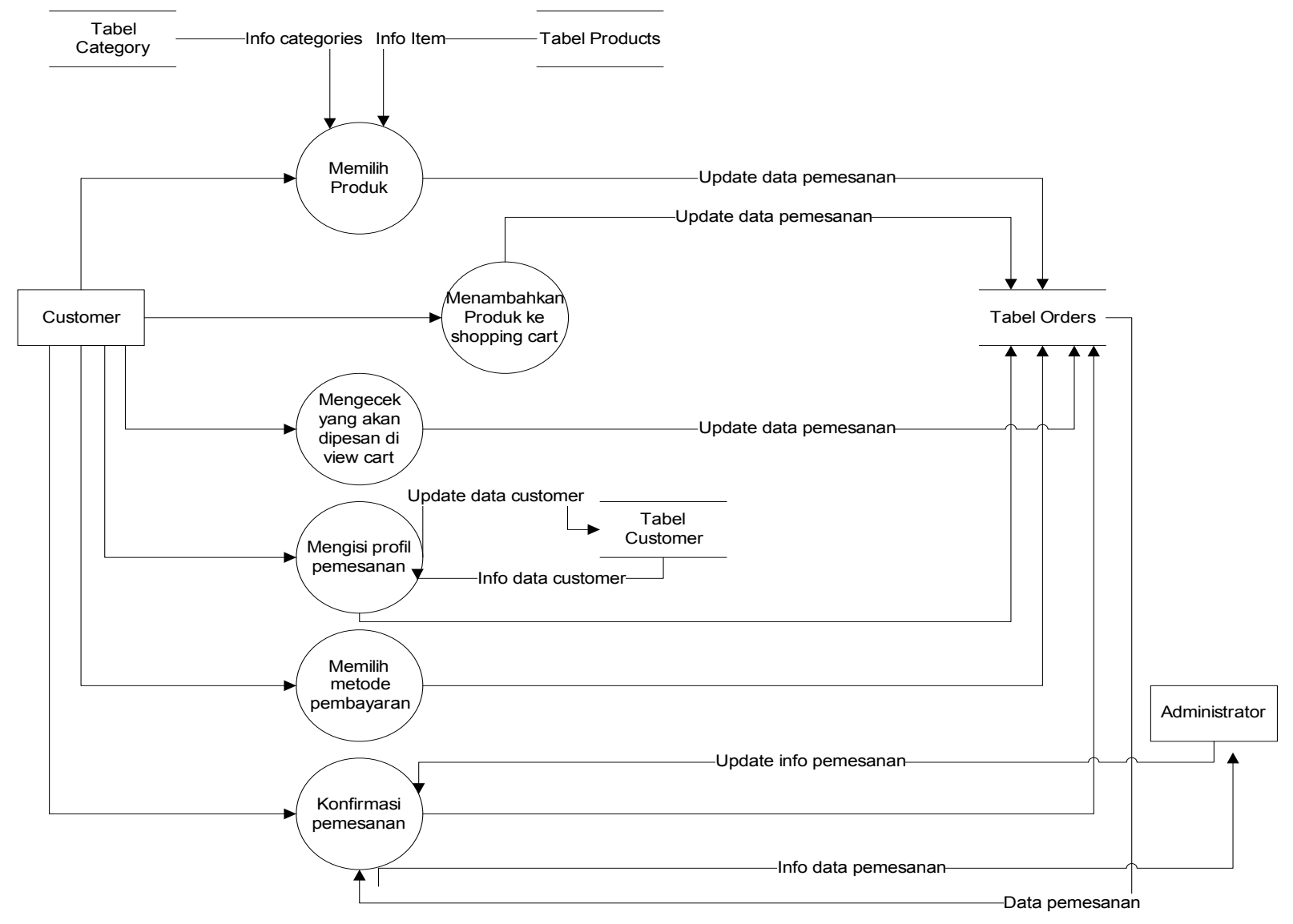

Gambar 6. DFD Level 1

pembelian diawali dengan memilih produk Produk yang telah dipilih akan masuk kedalam bag atau tas belanja. Customer melakukan proses pengecekan untuk mengetahui apakah produk yang masuk dalam tas belanja sudah sesuai. Jika produk yang dipesan sudah sesuai maka customer bisa melakukan proses checkout lalu mengisi semua prosedur diantaranya data customer, metode pengiriman, metode pembayaran, dan melakukan konfirmasi pemesanan.

\section{Implementasi Desain dan Perancangan}

Desain dan perancangan yang telah dibuat kemudian disambung ke dalam pembuatan websitehomeindustryabon. Berikut adalah tampilan dari hasil desain dan perancangan website.

\section{Halaman Utama}

Halaman ini merupakan halaman yang pertama kali diakses oleh pembeli. Halaman ini berisi beberapa sub menu antara lain sertifikat resmi,tentang kami, artikel ikan patin, artikel ikan lele, cara berlangganan dan kategori produk yang dijual oleh home industry abon. Halaman ini ditunjukkan pada Gambar 7.

\section{Halaman Kategori Produk}

Pada menu kategori produk berisi jenis produk serta tampilan produk serta harga jual produk abon. Tampilan kategori produk dapat dilihat pada Gambar 8.

Customer yang ingin melakukan pembelian produk tidak harus melakukan login terlebih dahulu. Customer bisa langsung melakukan proses pembelian diawali dengan memilih produk. Produk yang telah dipilih akan masuk ke dalam bag atau tas belanja. Customer melakukan proses pengecekan untuk mengetahui apakah produk yang masuk dalam tas belanja sudah sesuai. Jika produk yang dipesan sudah sesuai maka customer bisa melakukan proses checkout lalu mengisi semua prosedur diantaranya data customer, 


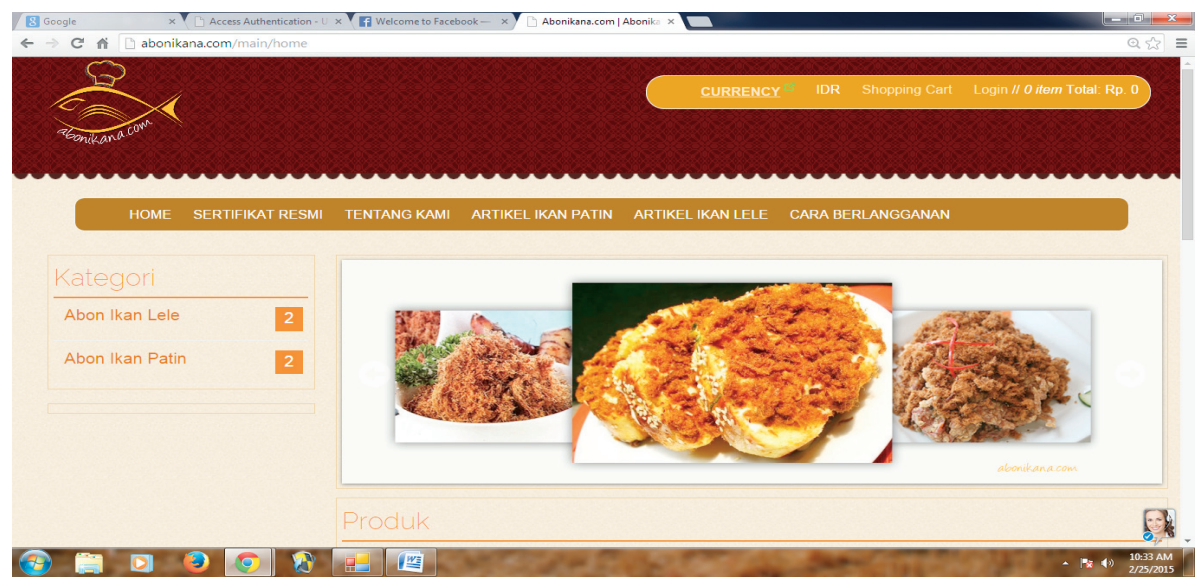

Gambar 7. Tampilan Halaman Utama

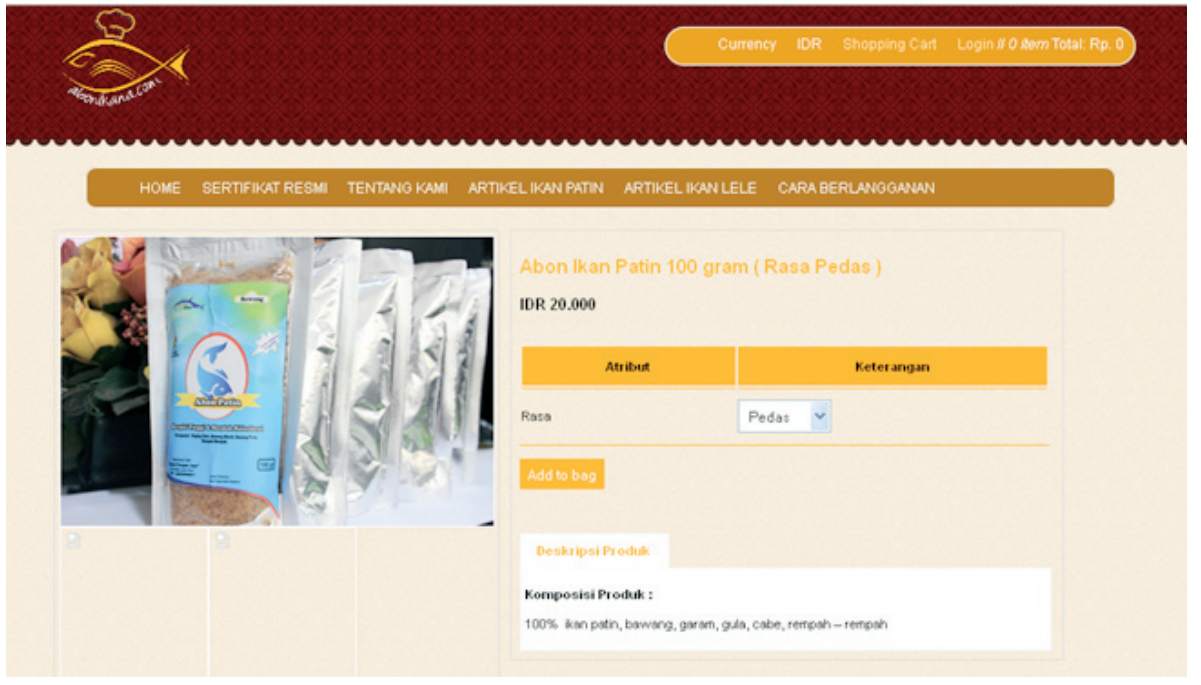

Gambar 8. Tampilan Halaman Kategori Produk

metode pengiriman, metode pembayaran, dan melakukan konfirmasi pemesanan. Pada Gambar 9 dapat dilihat tampilan pemesanan produk tanpa login.

\section{Halaman Login}

Customer yang sudah terdaftar bisa login terlebih dahulu sehingga tidak perlu lagi memasukkan data identitas customer. Tampilan halaman login bisa dilihat pada Gambar 10.

\section{Tampilan Sertifikat Resmi}

Halaman ini berisi informasi sertifikatsertifikat yang telah diperoleh home industry Lestari Jaya Pangan dari pemerintah dan dinas terkait yang menunjukkan bahwa usaha home industry telah mendapatkan ijin. Tampilan halaman sertifikat resmi bisa dilihat pada Gambar 11.

\section{Tampilan Tentang Kami}

Menu tampilan tentang kami berisi tentang profil usaha dan informasi tentang pemilik usaha. Tampilan menu tentang kami dapat dilihat pada Gambar 12.

\section{SIMPULAN}

Perancangan website dibuat dengan CMS opencart. Menu yang dibuat pada website ini adalah menu home, sertifikat resmi, kategori produk, tentang kami, artikel ikan patin, artikel ikan lele, dan cara berlangganan. Dengan adanya 


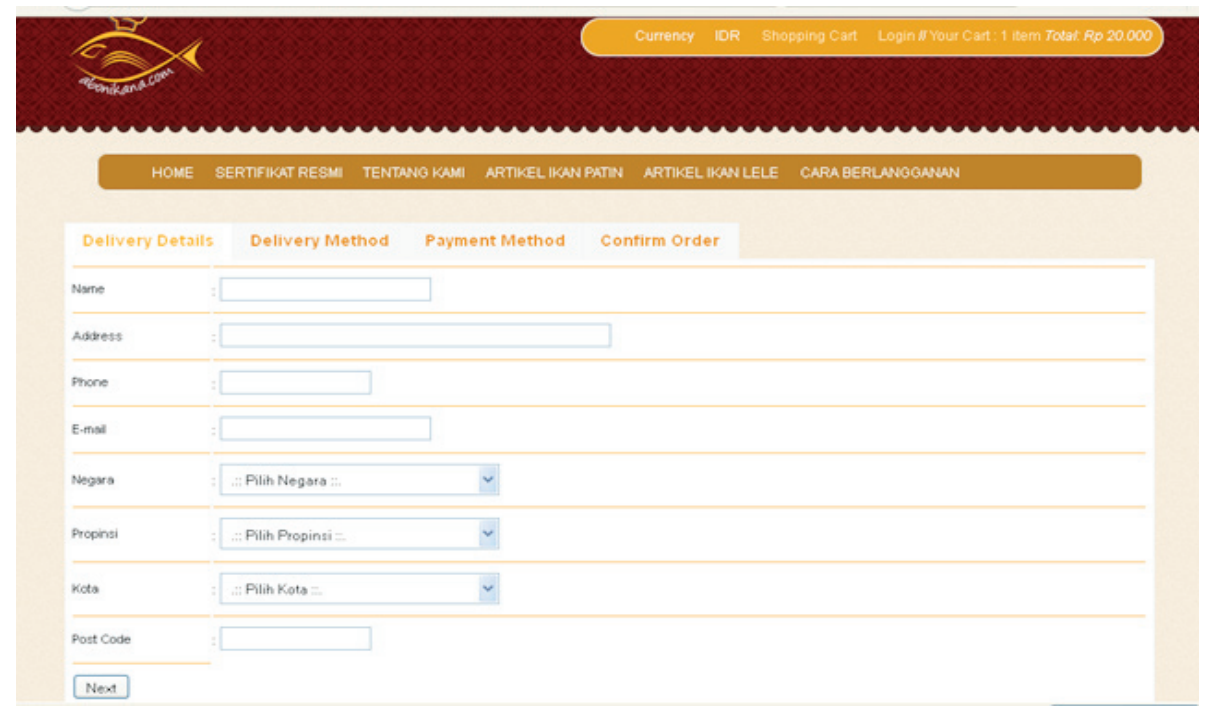

Gambar 9. Tampilan Pemesanan Produk

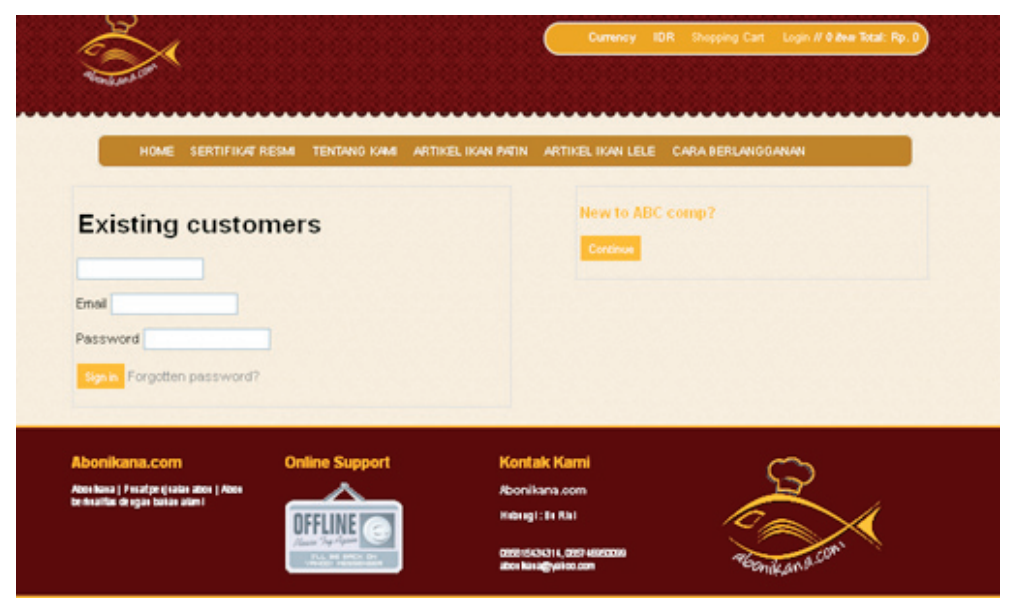

Gambar 10. Tampilan Halaman Login

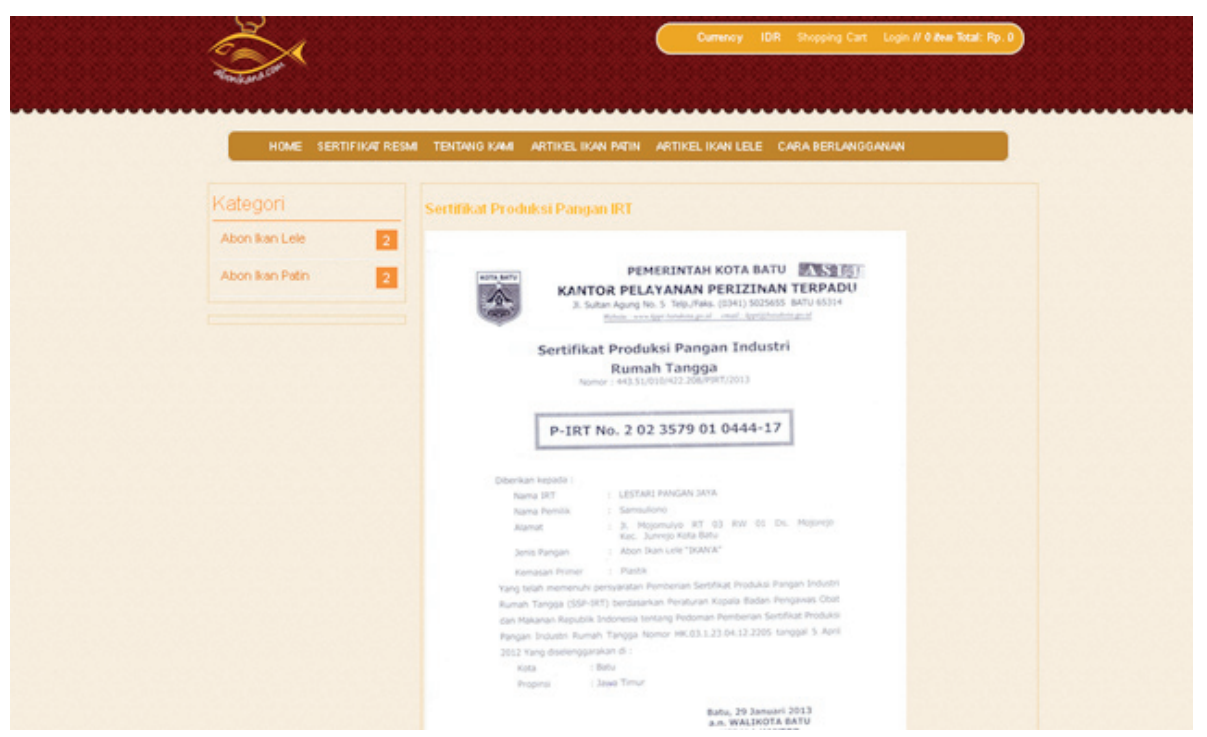

Gambar 11. Tampilan Halaman Sertifikat Resmi 


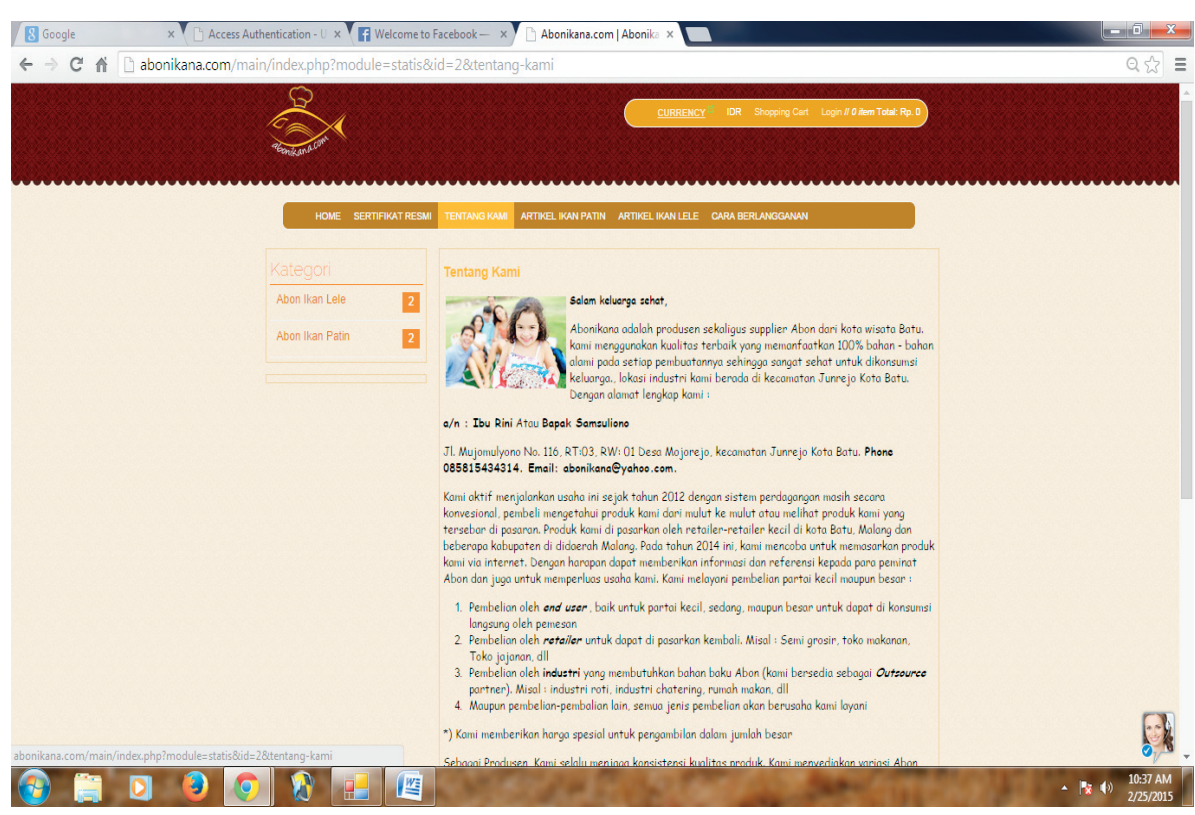

Gambar 12. Tampilan Halaman Tentang Kami

website e-commerce pada home industry Lestari Jaya Pangan maka kegiatan pemasaran lebih efektif dan bisa menaikkan omset penjualan.

\section{UCAPAN TERIMA KASIH}

Pada kesempatan ini, penulis mengucapkan terima kasih kepada DP2M-DIKTI atas dukungan dana dalam kegiatan Pengabdian IbM Tahun 2014.

\section{DAFTAR PUSTAKA}

Alexander, Y.Y., 2002. Enabling E-Commerce Growth Through The Social Construction Of A Virtual Community's Culture, Journal of Electronic Commerce Research, 3(4).

Fathansyah, 2001. Basis Data, Bandung : C.V. Informatika.

Gunadi, I.M dan Lirva32, 2007. Joomla Website Magic:dengan Joomla Bikin Website Semudah Memasak Mie Instan, Jakarta : Jasakom.

Iqbal, 2009. Rekayasa Content Management System (CMS) JOOMLA Berbasis Open Source untuk pengembangan Sistem Informasi Berbasis Online, Jurnal Informatika, 3(1),297-303.

Jauhari, J., 2010. Upaya Pengembangan Usaha Kecil dan Menengah (UKM) dengan Memanfaatkan E-Commerce, Jurnal Sistem Informasi, 2(1), 159-168.

Jinling, C., Tong, S., Chunan, L., and Tao, S., 2009. Modeling E-Commerce Website Quality with Quality Function Deployment, IEEE
International Conference on Deployment eBusiness Engineering.

Kendall, K.E. dan Kendall, J E., 2003. Analisis dan Perancangan Sistem, Edisi terjemahan, Jakarta: PT. Intan Sejati.

Kottler, P. dan Amstrong P., 2003. Manajemen Pemasaran, Edisi terjemahan, Jakarta : Salemba.

McLeod, R., 2004. Sistem Informasi Manajemen, Edisi terjemahan, Jakarta : Prenhallindo.

Nugrahani, D.S., 2011. E-Commerce untuk Pemasaran Produk Usaha Kecil dan Menengah, SEGMEN Jurnal Manajemen dan Bisnis, 1, 1-16.

Nugroho, B., 2004. Aplikasi Pemograman Web Dinamis dengan PHP dan MySQL, Yogyakarta : Gava Media

Quaddus, M. and Xu, J. 2008. Adoption of eCommerce: A Decision Theoretic Framework and an Illustrative Application, $10^{\text {th }}$ International Conference on Computer and Information Technology.

Rahmadi, R., 2010. Studi Komparatif Penggunaan Open Source Content Managament System (CMS) Joomla dan Drupal untuk Pembuatan Website, Jurnal Generic, 5(1).

Rizal, Bahauddin A., dan Ummi, N., 2013. Perancangan E-Commerce IKM Produk Industri Kreatif Kota Serang, Jurnal Teknik Industri, 1(4), 328 -333.

Syafrizal, M., 2005. Pengantar Jaringan Komputer, Yogyakarta: Andi Offset.

Supardi, J., 2009. Rancang Bangun Collaborative Sistem Pemasaran Hotel Secara On-line dengan Pendekatan Mediator Based, Jurnal Sistem Informasi, 1(2). 